\title{
Sulfur-inhibited Thermosphaera aggregans sp. nov., a new genus of hyperthermophilic archaea isolated after its prediction from environmentally derived 165 rRNA sequences
}

\author{
Robert Huber, Diana Dyba, Harald Huber, Siegfried Burggraf \\ and Reinhard Rachel
}

Lehrstuhl für Mikrobiologie und Archaeenzentrum, Universität Regensburg, Universitätsstr. 31, D-93053 Regensburg, Germany
Author for correspondence: Robert Huber. Tel: +49941 943 3182. Fax : + 499419432403. e-mail: Robert.Huber@biologie.uni-regensburg.de

Recently, a new procedure was developed which allowed for the first time the isolation of a hyperthermophilic archaeum tracked by 16 S rRNA analysis from a terrestrial hot solfataric spring ('Obsidian Pool', Yellowstone National Park, WY, USA). This novel isolate is characterized here. Cells are round cocci with a diameter of 0.2-0.8 $\mu \mathrm{m}$, occurring singly, in pairs, short chains and in grape-like aggregates. The aggregates exhibit a weak bluish-green fluorescence under UV radiation at $420 \mathrm{~nm}$. The new isolate is an anaerobic obligate heterotroph, using preferentially yeast extract for growth. The metabolic products include $\mathrm{CO}_{2}, \mathrm{H}_{2}$, acetate and isovalerate. Growth is observed between 65 and $90^{\circ} \mathrm{C}$ (optimum: $85^{\circ} \mathrm{C}$ ), from pH 5.0 to 7.0 (optimum: 6.5) and up to $0.7 \% \mathrm{NaCl}$. The apparent activation energy for growth is about $149 \mathrm{~kJ} \mathrm{~mol}^{-1}$. Elemental sulfur or hydrogen inhibits growth. The core lipids consist mainly of acyclic and cyclic glycerol diphytanyl tetraethers. The cell envelope contains a cytoplasmic membrane covered by an amorphous layer of unknown composition; there is no evidence for a regularly arrayed surface-layer protein. The $G+C$ content is $46 \mathrm{~mol} \%$. On the basis of $16 \mathrm{~S}$ rRNA sequence comparisons in combination with morphological, physiological and biochemical properties, the isolate represents a new genus within the Desulfurococcaceae, which has been named Thermosphaera. The type species is Thermosphaera aggregans, the type strain is isolate M11TL' ( $^{\top}$ DSM 11486').

Keywords: Thermosphaera aggregans sp. nov,, archaea, hyperthermophile, $16 \mathrm{~S}$ rRNA sequences

\section{INTRODUCTION}

Members of the Desulfurococcaceae are hyperthermophilic, anaerobic, coccoid to disk-shaped cells, belonging to the Crenarchaeota branch within the Archaea domain. They grow either chemolithoautotrophically by sulfur reduction or strictly heterotrophically by sulfur respiration or fermentation $(12,46$, $52,54,55)$. The family Desulfurococcaceae includes the genera 'Thermodiscus', 'Igneococcus', Desulfurococcus and Staphylothermus (12). Along with the type species Desulfurococcus mucosus (55), the genus Desulfurococcus $(12,55)$ also includes Desulfurococcus

The EMBL accession number for the M11TL 165 rRNA gene sequence reported in this paper is $X 99556$. mobilis (55), 'Desulfurococcus saccharovorans' (48), 'Desulfurococcus amylolyticus' (9) and two as-yetunnamed isolates S and SY (29). Members of Desulfurococcus were found in continental solfatara fields $(9,49,55)$ and hydrothermal vent sites $(29)$. The genus Staphylothermus is currently only represented by the type species Staphylothermus marinus (15), which has been isolated from both shallow and abyssal marine hydrothermal systems (15).

Cells of Desulfurococcus are coccoid and occur singly and in pairs (55), whereas Staphylothermus grows mainly in grape-like aggregates (15). They thrive under anaerobic conditions preferentially on complex organic substrates such as yeast extract, meat extract, bacterial and archaeal cell extracts, peptone, casein, starch or glycogen $(9,15,19,55)$. As metabolic 
products, $\mathrm{CO}_{2}, \mathrm{H}_{2}$, acetate, isovalerate, isobutyrate and $\mathrm{H}_{2} \mathrm{~S}$ (in sulfur-containing media) were identified $(15,19,55)$. Members of the genus Desulfurococcus are not strictly sulfur-dependent but growth is stimulated by sulfur $(9,55)$. On the other hand, Staphylothermus marinus is strictly sulfur-dependent when grown as pure culture (15). However, in the absence of sulfur, it can be grown in syntrophic culture together with $\mathrm{H}_{2}$ consuming organisms (10). In contrast, inhibition of growth by sulfur was found recently in the hyperthermophiles Pyrobaculum aerophilum (51) and Pyrolobus fumarii (6), both growing either by microaerophilic or by anaerobic nitrate respiration.

A great phylogenetic variety of cultured hyperthermophiles is already known (47). However, in situ $16 \mathrm{~S}$ rRNA gene sequence analyses of samples from 'Obsidian Pool' (Yellowstone National Park, WY, USA) revealed many unknown archaeal sequences, indicating the existence of many as-yet-uncultivated species $(3,4)$. Recently, a new procedure was developed, which allowed for the first time the isolation of a hyperthermophilic archaeum $\left(\mathrm{M} 11 \mathrm{TL}^{\mathrm{T}}\right)$ from this natural environment by the combination of in situ $16 \mathrm{~S}$ rRNA analyses, specific cell hybridization within enrichment cultures and 'selected cell isolation' by the use of a laser microscope ('optical tweezers'; 4, 21). In an independent approach, Kane et al. (30) enriched and isolated a sulfate-reducing bacterium from an anaerobic laboratory bioreactor, originally identified as a molecular isolate phylogenetically related to Desulfovibrio vulgaris.

Here we characterize the novel isolate $\mathrm{M} 11 \mathrm{TL}^{\mathrm{T}}$, the 16S rRNA sequence of which is identical to that of clone pSL91, known from 'Obsidian Pool' (4). It represents a new genus within the Desulfurococcaceae, the type species of which we name Thermosphaera aggregans.

\section{METHODS}

Collection of samples, enrichment and isolation. Sampling, enrichment and isolation of the new organism was described recently by Huber et al. (21).

Strains and culture conditions. For stock maintenance and experimental studies, the new isolate $\mathrm{M} 11 \mathrm{TL}^{\mathrm{T}}$ was cultivated in a medium containing the following components $\left(1^{-1}\right)$ : $2.2 \mathrm{~g} \mathrm{MgCl} .6 \mathrm{H}_{2} \mathrm{O}, 1.0 \mathrm{~g} \mathrm{NaHCO}_{3}, 0.9 \mathrm{~g} \mathrm{NaCl}, 17 \mathrm{mg} \mathrm{KCl}$, $12.5 \mathrm{mg} \mathrm{NH}{ }_{4} \mathrm{Cl}, 7.0 \mathrm{mg} \mathrm{CaCl} 2,2 \mathrm{H}_{2} \mathrm{O}, 7.0 \mathrm{mg} \mathrm{K} \mathrm{HPO}_{4} .3$ $\mathrm{H}_{2} \mathrm{O}, 0.05 \mathrm{mg} \mathrm{Fe}(\mathrm{III}) \mathrm{Cl}_{3}, 10 \mathrm{ml}$ vitamin solution (2), $1.0 \mathrm{~g}$ Bacto yeast extract (Difco), $1.0 \mathrm{~g}$ Bacto peptone (Difco), $0.02 \mathrm{mg}$ resazurine. The medium was reduced by the addition of $0.5 \mathrm{~g} \mathrm{Na}_{2} \mathrm{~S} .9 \mathrm{H}_{2} \mathrm{O}$. The $\mathrm{pH}$ was adjusted to 6.5 with $\mathrm{HCl}$. Strictly anaerobic culture media were prepared according to the anaerobic technique of Balch \& Wolfe (1). Unless stated otherwise, the gas phase consisted of $300 \mathrm{kPa} \mathrm{N} \mathrm{N}_{2} / \mathrm{CO}_{2}$ $(80: 20)$. Isolate $\mathrm{M} 11 \mathrm{TL}^{\mathrm{T}}$ was routinely grown at $85^{\circ} \mathrm{C}$ and approximately 60 r.p.m. in $28 \mathrm{ml}$ serum tubes (borate silicate glass, Schott) containing $10 \mathrm{ml}$ medium. For the determination of $\mathrm{pH}$ dependence of growth, cultures were grown in $100 \mathrm{ml}$ flasks (Schott) in the presence of $200 \mathrm{kPa} \mathrm{N}$. When organic compounds other than yeast extract or peptone were tested as substrates, the yeast extract and peptone concentration was reduced to $0.005 \%(\mathrm{w} / \mathrm{v})$. To determine the optimal $\mathrm{NaCl}$ concentration for growth, only the medium $\mathrm{NaCl}$ was varied, while the concentration of all other salts remained the same.

Determination of growth. Cell densities were determined by direct cell counting using a Thoma chamber (depth $0.02 \mathrm{~mm}$ ).

Effect of temperature on growth rate. Influence of temperature on growth was assayed by the quantitative determination of the whole cell protein concentration as described $(34,42)$. For this experiment, $M 11 \mathrm{TL}^{\mathrm{T}}$ was grown at different temperatures in 11 culture bottles containing $250 \mathrm{ml}$ medium. During growth, $20 \mathrm{ml}$ samples were taken at different time intervals and the cells were collected by centrifugation (Beckman J2-21 centrifuge, $30 \mathrm{~min}, 4^{\circ} \mathrm{C}$; rotor: JA20). To solubilize the cells, the centrifuged cell sediment was resuspended in $100 \mu \mathrm{LDS}(5 \%)$ followed by incubation at $100^{\circ} \mathrm{C}$ for $15 \mathrm{~min}$. For protein determination, $100 \mu \mathrm{l}$ solubilized cell material was incubated with $500 \mu \mathrm{l}$ reagent $A^{\prime}$ and $4 \mathrm{ml}$ reagent $B$ of the Bio $\operatorname{Rad} D C$ Protein assay (Bio Rad). The protein concentration was determined spectrophotometrically $(750 \mathrm{~nm}$; Beckman). A BSA standard containing $0.03-1.5 \mathrm{mg}$ protein $\mathrm{ml}^{-1}$ was used. The protein concentration was used to determine the respective growth rate constant $\mathrm{k}$. The logarithm of $\mathrm{k}$ was plotted against the reciprocal of the absolute temperature and the apparent activation energy for growth was calculated from an Arrhenius plot (18).

Light and electron microscopy. Cells were observed with a Zeiss standard phase-contrast microscope (Oberkochen) equipped with an oil-immersion objective $(\times 100 / 1 \cdot 3)$. Micrographs were taken on a Zeiss Axiovert 35 inverse phase-contrast microscope with a Olympus OM3 camera. To bring the cells into a horizontal position, the organisms were allowed to settle down onto the cover slide for approximately $30 \mathrm{~min}$. Electron microscopy was carried out as described (24). For ultrathin sections, cells, fixed with $1 \%$ glutaraldehyde in the culture medium, were freeze-substituted in diethyl ether (containing molecular sieve, $0 \cdot 4 \mathrm{~nm}$ ).

Detection of metabolic products. Acetate and isovalerate were determined by HPLC (25), $\mathrm{H}_{2}$ and $\mathrm{CO}_{2}$ by GC according to the methods of Huber et al. $(26,28)$. Methane was determined with a Hewlett-Packard 5890 gas chromatograph equipped with a Molecular Sieve $5 \mathrm{~A}$ column (Supelco) and a flame ionization detector (oven temperature: $140^{\circ} \mathrm{C}$; detector and injector temperature: $170^{\circ} \mathrm{C}$ ). $\mathrm{H}_{2} \mathrm{~S}$ was detected qualitatively by addition of $20 \mu \mathrm{l}$ saturated lead acetate solution to $0.5 \mathrm{ml}$ samples. A dark brown precipitate demonstrated its presence.

Following growth on heat-treated xylan $\left(121^{\circ} \mathrm{C}, 20 \mathrm{~min}\right)$, the reducing sugars formed by $\mathrm{M} 11 \mathrm{TL}^{\mathrm{T}}$ were determined by the 3,5-dinitrosalicylic acid (DNSA) method, according to Miller (38). DNSA solution ( $750 \mu \mathrm{l})$ was added to a $500 \mu \mathrm{l}$ sample, incubated for $20 \mathrm{~min}$ at $90^{\circ} \mathrm{C}$, and the colour reaction was measured spectrophotometrically at $595 \mathrm{~nm}$.

Lipid analysis. Lipids were extracted from cell mass as described by Huber et al. (25). The core lipids were identified by TLC (50). As reference substances, extracted core lipids of Thermococcus stetteri (39) and Pyrobaculum organotrophum (23) were used.

DNA isolation and base composition. DNA was isolated as described by Lauerer et al. (33). The $\mathrm{G}+\mathrm{C}$ content was 
determined by melting point analysis (36), with calf thymus DNA $(42 \mathrm{~mol} \% \mathrm{G}+\mathrm{C})$ as a reference.

DNA-DNA hybridization. DNA-DNA hybridization was carried out after radioactive in vitro labelling of the DNA (31) with a nick translation reagent kit (BRL) using the filter technique as described previously $(16,32)$. The hybridization took place for $20 \mathrm{~h}$ at $66^{\circ} \mathrm{C}$ in $3 \times \operatorname{SSC}\left(25^{\circ} \mathrm{C}\right.$ below $T_{\mathrm{m}}=$ 'optimal' conditions; $7,35,37$ ), where $1 \times$ SSC is $0.15 \mathrm{M}$ sodium chloride plus $0.015 \mathrm{M}$ sodium citrate. The amount of radioactivity bound (in c.p.m.) in the homologous filters (for example, 396000 c.p.m. for M11TL ${ }^{\mathrm{T}}$ ) was set as $100 \%$ homology and compared with the activity of the heterologous filters.

16S rRNA analysis. 16S rDNA was amplified by PCR $(40,43$, 44). The primers employed in the amplification had the sequences CTY GGT TGA TCC TGC C and CGG HTA CCT TGT TAC GAC TT and corresponded to position 8-23 and 1511-1492 respectively in the 16S rRNA (Escherichia coli numbering, 11). Both strands of the PCR product were sequenced (1414 positions determined) and the analysis of the sequence data was performed according to the methods of Burggraf et al. (12).

\section{RESULTS}

\section{Morphology}

Cells of the isolate $\mathrm{M} 11 \mathrm{TL}^{\mathrm{T}}$ were regular cocci. During the exponential growth phase, they grew predominantly in grape-like aggregates consisting of five to several hundred individuals. Under the UV microscope at $420 \mathrm{~nm}$, these aggregates exhibited a weak bluish-green fluorescence which faded rapidly under UV radiation. The aggregates with diameters up to $10 \mu \mathrm{m}$ could not be disintegrated into single cells by supersonic treatment, mechanical stirring, enzyme treatment (trypsin, proteinase $\mathrm{K}$, cellulase) or periodic acid $(0.7 \%, \mathrm{w} / \mathrm{v})$. In the late-logarithmic and stationary growth phases, smaller aggregates, single cells, duplex forms and short chains with up to four cocci were visible (Figs 1, 2a). The diameter of the cells varied between 0.2 and $0.8 \mu \mathrm{m}$. Morphology was influenced by culture conditions: at the upper temperature limit of growth $\left(90^{\circ} \mathrm{C}\right)$ or in the presence of sulfur (e.g. $0.05 \%$, final concn), single cells up to

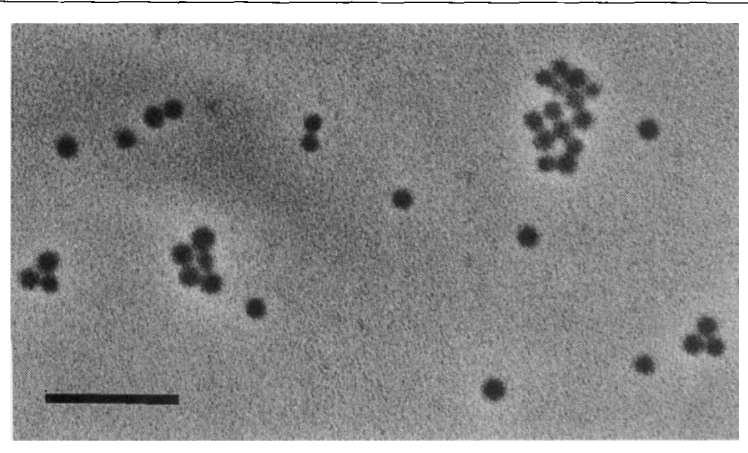

Fig. 1. Phase-contrast micrograph of cells of Thermosphaera aggregans during the late-exponential growth phase. Bar, $5 \mu \mathrm{m}$.
$3.5 \mu \mathrm{m}$ in diameter containing one or two dark granules became visible.

Grape-like cell aggregates possessed several flagella (Fig. 2a), single cells possessed up to eight flagella. Ultrathin sections of freeze-substituted cells revealed a cytoplasmic membrane $(4 \mathrm{~nm})$, plus an amorphous layer, approximately 10-15 nm thick (Fig. 2b). In a micrograph of a freeze-etched cell aggregate, no regular lattice, indicative of a surface-layer protein, was detected (Fig. 2c). The fracture face revealed a fine granular cytoplasm (Fig. 2c).

\section{Physiological characterization}

M11TL $\mathrm{TL}^{\mathrm{T}}$ grew from 67 to $90^{\circ} \mathrm{C}$ with an optimal doubling time of $110 \mathrm{~min}$ at $85^{\circ} \mathrm{C}$ (Fig. 3). No growth occurred at 65 or $92{ }^{\circ} \mathrm{C}$. The Arrhenius plot yielded a straight line between growth temperatures of 75 and $85^{\circ} \mathrm{C}$. The apparent activation energy for growth calculated from the mid-zone was about $149 \mathrm{~kJ} \mathrm{~mol}^{-1}$.

Growth of isolate $\mathrm{M}^{11 \mathrm{TL}^{\mathrm{T}}}$ occurred between $\mathrm{pH} 5 \cdot 0$ and 7.0 with an optimum of 6.5 . No growth was observed at $\mathrm{pH} 4.5$ or $7 \cdot 5 . \mathrm{M} 11 \mathrm{TL}^{\mathrm{T}}$ grew when between 0 and $0.7 \% \mathrm{NaCl}$ was added to the medium. To adapt cultures to $\mathrm{NaCl}$ concentrations above $0.4 \%$, the $\mathrm{NaCl}$ concentration was increased stepwise by $0 \cdot 1 \%$ during each culture transfer. Growth was optimal in the absence of exogenous $\mathrm{NaCl}$.

\section{Metabolism}

In closed serum tubes, isolate $\mathrm{M} 11 \mathrm{TL}^{\mathrm{T}}$ grew strictly heterotrophically with yeast extract (final concentration $0.1 \%, \mathrm{w} / \mathrm{v})$ and peptone $(0.1 \%)$ under anaerobic culture conditions up to cell titres of about $2 \times 10^{8}$ cells $\mathrm{ml}^{-1}$. With yeast extract as single substrate, titres of about $1 \times 10^{8}$ cells $\mathrm{ml}^{-1}$ were obtained. Maximal cell densities of M11TL ${ }^{\mathrm{T}}$ with up to $4 \times 10^{8}$ cells $\mathrm{ml}^{-1}$ were obtained by flushing exponentially growing cultures periodically with $\mathrm{N}_{2} / \mathrm{CO}_{2}(80: 20)$ to remove hydrogen, a product of fermentation (see below) that is a potent growth inhibitor for this species. No growth occurred, when cultures were pressurized with hydrogen-containing gas $\left(200 \mathrm{kPa} \mathrm{N} / \mathrm{CO}_{2}=\right.$ $80: 20+100 \mathrm{kPa} \mathrm{H}_{2} / \mathrm{CO}_{2}=80: 20$ ). This inhibition was reversible, for growth resumed after gas exchange $\left(300 \mathrm{kPa} \mathrm{N}{ }_{2} / \mathrm{CO}_{2}=80: 20\right)$.

No growth was observed on native xylan (final concentration $0.2 \%, \mathrm{w} / \mathrm{v})$ or xylose $(0 \cdot 1 \%)$. However, growth took place on heat-treated xylan $(0.2 \%)$ with cell densities of about $7 \times 10^{7}$ cells $\mathrm{ml}^{-1}$. After growth, an increase of reducing sugars in the culture medium was detected. Furthermore, growth was observed on gelatin $(0.2 \%)$, on a defined mixture of amino acids $(0.04 \%)$ and on glucose $(0.1 \%)$, yielding cell densities of only $2-5 \times 10^{7}$ cells $\mathrm{ml}^{-1}$. No growth occurred on meat extract, bovine heart infusion, peptone, amylose, glycogen, cellulose, cellobiose, maltose, raffinose, pyruvate and acetate (final concentration $0 \cdot 1 \%, \mathrm{w} / \mathrm{v}$ ). 

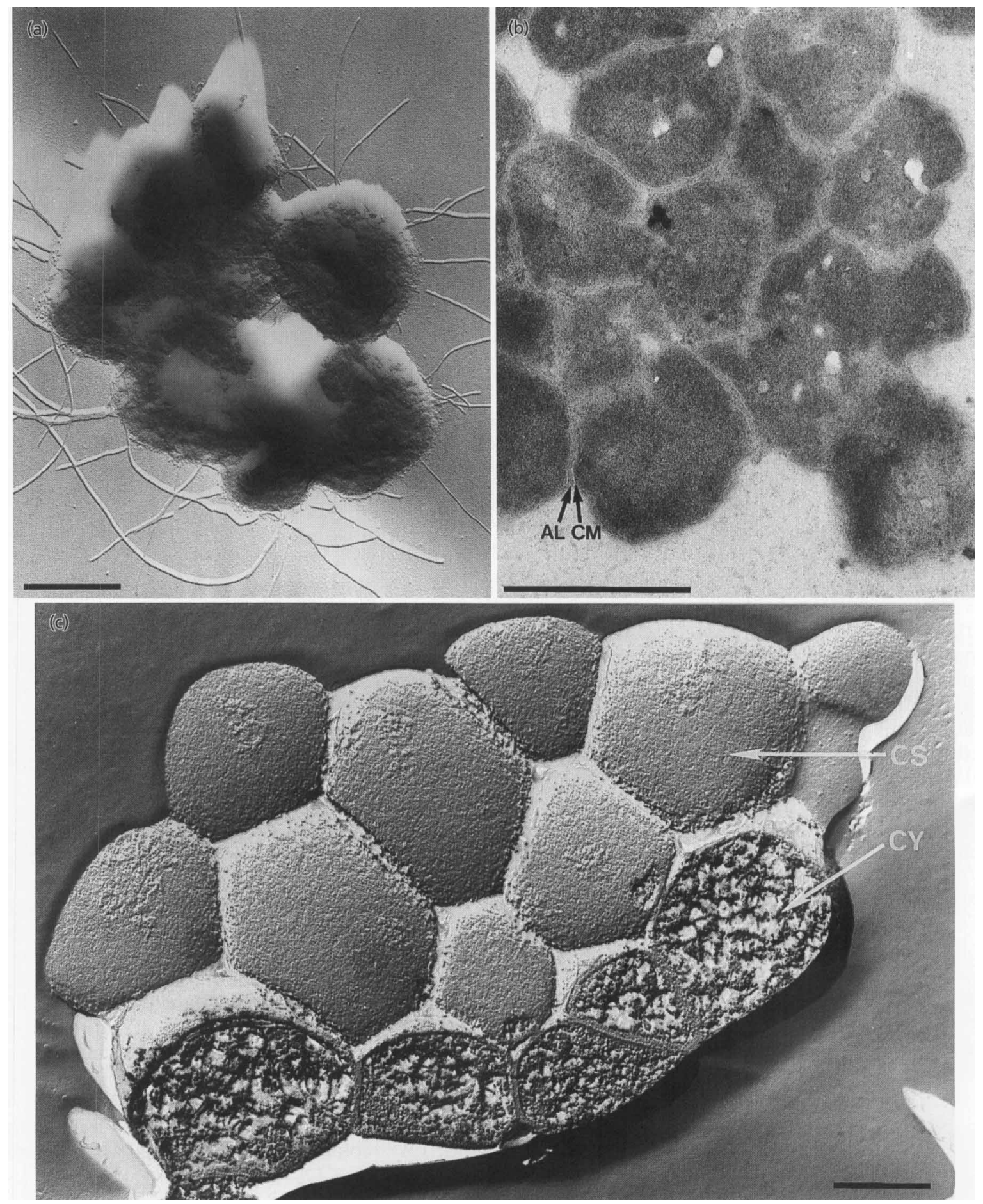

Fig. 2. (a). Electron micrograph of a grape-like cell aggregate of Thermosphaera aggregans (air-dried and platinumshadowed). (b) Ultrathin section of a freeze-substituted cell aggregate of Thermosphaera aggregans. Arrows point to the cytoplasmic membrane (CM) and to the amorphous layer (AL). (c) Electron micrograph of a freeze-etched cell aggregate of Thermosphaera aggregans. Arrows point to the cell surface (CS) and to the cytoplasm (CY) of a fractured cell. Bars, $0.5 \mu \mathrm{m}$.

Elemental sulfur was a potent inhibitor of growth. Even at the very low concentration of $0.05 \%(\mathrm{w} / \mathrm{v})$, only about $10 \%$ of the final cell titres were determined compared to cultures without sulfur. When $0.05 \%$ sulfur was added to exponentially growing cultures, cell growth stopped. During further incubation, $\mathrm{H}_{2} \mathrm{~S}$ 


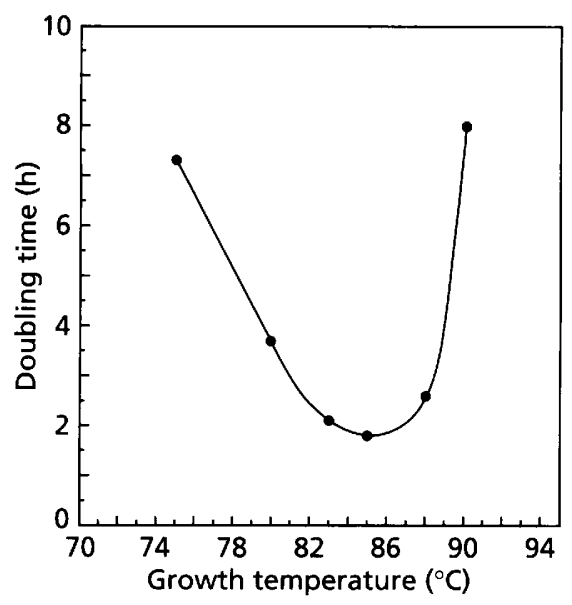

Fig. 3. Effect of temperature on growth of Thermosphaera aggregans.

was formed in large amounts and cells began to lyse. Similar observations have been reported for methanogens and hyperthermophilic sulfate-reducers $(13,56)$. Sulfide did not inhibit growth of M11TL ${ }^{\mathrm{T}}$, when added to the medium in the same concentration as sulfur.

When M11TL ${ }^{\mathbf{T}}$ was cultivated on yeast extract and peptone, isovalerate, acetate, $\mathrm{CO}_{2}$ and $\mathrm{H}_{2}$ were identified as fermentation products.

\section{Lipid composition}

Thin-layer chromatograms of the core lipids of M11TL ${ }^{\mathrm{T}}$ showed mainly acyclic $\left(R_{\mathrm{f}}\right.$ value 0.43$)$ and cyclic glycerol diphytanyl tetraethers with one to four pentacyclic rings $\left(R_{\mathrm{f}}\right.$ values $0.4,0.39,0.37,0.35$, respectively). Traces of glycerol diphytanyl diethers $\left(R_{\mathrm{f}} 0.75\right)$ were detected in addition.

\section{DNA base composition, DNA-DNA hybridization and 165 rRNA phylogeny}

The $\mathrm{G}+\mathrm{C}$ content of isolate $\mathrm{M} 11 \mathrm{TL}^{\mathrm{T}}$ was $46 \mathrm{~mol} \%$, as determined by melting point analysis (36).

In DNA-DNA hybridization studies, DNA of isolate M11TL ${ }^{\mathrm{T}}$ showed no hybridization signal with the isolated DNA of Staphylothermus marinus and Desulfurococcus mobilis.

By $16 \mathrm{~S}$ rRNA sequence comparisons, isolate $\mathrm{M} 11 \mathrm{TL}^{\mathrm{T}}$ was identified as a member of the Crenarchaeota within the domain Archaea. The closest relatives of M11TL ${ }^{\mathrm{T}}$ are members of the genera Desulfurococcus and Staphylothermus, as indicated by an estimated exchange of 3.5 and 3.9 nucleotides per 100 positions, respectively (12). Fig. 4 shows the phylogenetic relationship of $\mathrm{M}^{1} 1 \mathrm{TL}^{\mathrm{T}}$ with other members of the Crenarchaeota.

\section{DISCUSSION}

Based on 16S rRNA sequence comparisons, the novel isolate $\mathrm{M} 11 \mathrm{TL}^{\mathrm{T}}$ was identified as a member of the Crenarchaeota. Within this branch, M11TL ${ }^{\mathrm{T}}$ was clearly affiliated to the Desulfurococcaceae with closest relationship to Staphylothermus and Desulfurococcus $(12,15,55)$. However, M11TL ${ }^{\mathrm{T}}$ differs in several important phenotypical properties from Staphylothermus and Desulfurococcus. A considerable difference to these genera is obvious with respect to the utilization of sulfur. In contrast to the sulfur-respiring Desulfurococcus and Staphylothermus, growth of M11TL ${ }^{\mathrm{T}}$ is prevented in the presence of elemental sulfur. This sulfur inhibition was unexpected, because all other genera within the Desulfurococcaceae respire sulfur (12). However, within other main phylogenetic branches of the Crenarchaeota, the type of metabolism also varies. Within the otherwise strictly anaerobic,

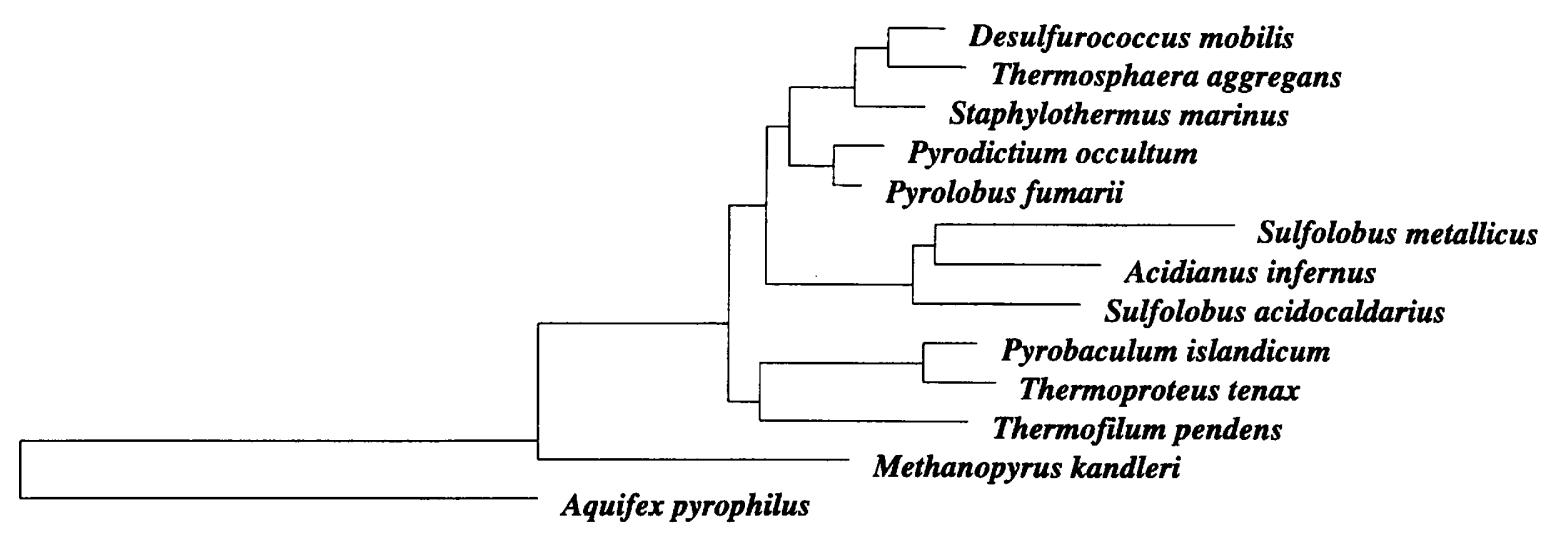

$0 \cdot 10$

Fig. 4. Phylogenetic tree of Thermosphaera aggregans and various members of the Crenarchaeota derived from 165 rDNA sequence data, using the neighbour-joining method for calculation. Methanopyrus kandleri belongs to the Euryarchaeota and Aquifex pyrophilus to the Bacteria. The scale bar indicates 10 estimated changes per 100 nucleotides. 
sulfur-respiring Thermoproteales and Pyrodictiaceae (12), Pyrobaculum aerophilum (51) and Pyrolobus fumarii (6) utilize aerobic or anaerobic respiration with nitrate. Furthermore, Stygiolobus azoricus (45), a strictly anaerobic member of the Sulfolobales, is the closest relative of the strict aerobe Sulfolobus acidocaldarius (8). In view of those unexpected properties, it is not always justified to infer the metabolic type based upon the metabolic properties of the phylogenetic relatives.

In contrast to Desulfurococcus, $\mathrm{M}_{11 \mathrm{TL}^{\mathrm{T}}}$ grows in large, grape-like cell aggregates similar to Staphylothermus. However, cell aggregates of $\mathrm{M}_{11 \mathrm{TL}^{\mathrm{T}}}$ exhibit a bluish-green fluorescence at $420 \mathrm{~nm}$. The source of this fluorescence is unknown. A unique feature of $\mathrm{M}^{11 \mathrm{TL}^{\mathrm{T}}}$ is evident in its cell architecture, with no surface-layer protein being detectable: there is no evidence for a regular surface lattice like that in Desulfurococcus or any other members of the Crenarchaeota (12), nor for a structure like the tetrabrachion of Staphylothermus (Fig. 2c; 41, 53).

M11TL ${ }^{T}$ is also unique in the composition and structural features of its core lipids. In contrast to Staphylothermus and Desulfurococcus, where glycerol diphytanyl diether- and acyclic glycerol diphytanyl tetraether lipids have been identified, acyclic tetraethers and cyclic tetraethers with one to four pentacyclic rings are the predominant lipids in $\mathrm{M}_{11 \mathrm{TL}^{\mathrm{T}}}(14$, 15). The occurrence of cyclic tetraether lipids in members of the Desulfurococcaceae was so far unknown and emphasizes again the uniqueness of $\mathrm{M} 11 \mathrm{TL}^{\mathrm{T}}$ within this family.

The evolutionary distances between isolate $\mathrm{M}_{11 \mathrm{TL}^{\mathrm{T}}}$ and its nearest relatives Staphylothermus marinus and Desulfurococcus mobilis are 3.9 and $3.5 \%$, respectively (12). This divergence is similar to that between the genera Staphylothermus and Desulfurococcus or Pyrobaculum and Thermoproteus (12), which indicates that isolate $\mathrm{M}_{11 \mathrm{TL}^{\mathrm{T}}}$ represents a new genus. The significance of these differences is also evident in the branching of the 16S rRNA phylogenetic tree, which strengthens this criterion (Fig. 4) and is also reflected in hybridization studies by the lack of significant DNA homology.

Therefore, on the basis of 16S rRNA sequence comparisons as the main criterion, in combination with unique morphological, physiological and biochemical properties, we propose that $\mathrm{M} 11 \mathrm{TL}^{\mathrm{T}}$ represents a new genus, which we describe here as Thermosphaera ('the hot sphere'). The type species is Thermosphaera aggregans, type strain Thermosphaera aggregans, isolate M11TL ${ }^{\mathrm{T}}$ (DSM 11486).

Growth of Thermosphaera aggregans occurs within a temperature range of $25^{\circ} \mathrm{C}$ similar to many hyperthermophilic archaea (5). From 75 to $85^{\circ} \mathrm{C}$, Thermosphaera aggregans grows within the Arrhenius relation with an activation energy of $149 \mathrm{~kJ} \mathrm{~mol}^{-1}$, which is significantly higher than that decribed for mesophilic and psychrophilic bacteria $(17,27)$.
Recently, we were able to isolate additional hyperthermophiles from the 'Obsidian Pool' (22); their presence was predicted from extraction and sequencing of DNA from this site $(3,4)$. One of the isolates is S10TFL (sequence identical to clone sequence pJP6; 3 , 12 ), a strict anaerobe, which grows preferentially on archaeal cell extracts (22). S10TFL and Thermosphaera aggregans use different biopolymers for growth, and therefore together they act as degraders of organic matter in their biotope. Thermosphaera aggregans produces isovalerate, acetate, hydrogen and $\mathrm{CO}_{2}$, and can provide growth substrates for other hyperthermophiles present in the 'Obsidian Pool'. One of these consumers is a new isolate $\mathrm{S} 10 \mathrm{~L}$ (sequence identical to clone sequence pSL23; 4), which represents a novel, hyperthermophilic sulfate-reducer (22).

\section{Description of Thermosphaera gen. nov.}

Thermosphaera (Ther.mo.sphae'ra. Gr. fem. n. therme, heat; L. fem. n. sphaera, sphere; L. fem.n. Thermosphaera, the hot sphere).

Cells are cocci, occurring singly, in pairs, in short chains and in aggregates. No spores formed. Cell envelope consists of a cytoplasmic membrane with an amorphous layer on top. Membrane contains acyclic and cyclic glycerol diphytanyl glycerol tetraethers. Growth up to $90{ }^{\circ} \mathrm{C}$ and up to $0.7 \% \mathrm{NaCl}$. Anaerobic. Strictly heterotrophic. Growth by fermentation. Sulfur or hydrogen inhibits growth. DNA base composition $46 \mathrm{~mol} \% \mathrm{G}+\mathrm{C}$. No significant DNA homology with Staphylothermus marinus and Desulfurococcus mobilis. By 16S rRNA analysis, Thermosphaera represents a new genus belonging to the Desulfurococcaceae. Habitat: solfataric hot spring.

The type species is Thermosphaera aggregans.

\section{Description of Thermosphaera aggregans sp. nov.}

Thermosphaera aggregans ( $\mathrm{ag}^{\prime}$.gre.gans. L. v. aggregare to aggregate, referring to the ability of the cells to form grape-like aggregates).

Cells are cocci from 0.2 to $0.8 \mu \mathrm{m}$ in diameter, occurring singly, in pairs, in short chains and in grapelike aggregates. During growth, aggregates up to $10 \mu \mathrm{m}$ with several hundred individuals visible. Cell aggregates exhibit a bluish-green fluorescence at $420 \mathrm{~nm}$. Spores are not formed. Flagella present. Cell envelope composed of a cytoplasmic membrane (width: $4 \mathrm{~nm}$ ), covered by an amorphous layer, $10-15 \mathrm{~nm}$ thick. No evidence for a regular arrayed surface-layer protein. Core lipids consist mainly of acyclic and cyclic glycerol diphytanyl glycerol tetraethers with one to four pentacyclic rings. Growth between 67 and $90^{\circ} \mathrm{C}$ (optimum: $85^{\circ} \mathrm{C}$ ), pH 5.0-7.0 (optimum: 6.5) and $0-0.7 \% \mathrm{NaCl}$ (optimum: $0 \%$ ). Optimal doubling time $110 \mathrm{~min}$. Anaerobic. Heterotrophic growth with yeast extract. Peptone stimulates growth. $\mathrm{CO}_{2}, \mathrm{H}_{2}$, acetate and isovalerate formed as metabolic products. Growth inhibition by sulfur or hydrogen. $\mathrm{G}+\mathrm{C}$ content $46 \mathrm{~mol} \% .3 .9$ and $3.5 \%$ 
evolutionary distance to Staphylothermus marinus and Desulfurococcus mobilis, respectively.

The type strain is isolate $\mathrm{M}_{11 \mathrm{TL}^{\mathrm{T}}}$, DSM 11486 , Braunschweig, Germany (isolated from 'Obsidian Pool' in the Mud Volcano area of Yellowstone National Park, WY, USA).

\section{ADDENDUM IN PROOF}

After this work was submitted for publication, Hensel et al. (Syst Appl Microbiol 20, 102-110, 1997) published Sulfophobococcus as a new genus within the Crenarchaeota with closest relationship to Desulfurococcus. Comparison of 16S rRNA sequences and conserved bases in the 16S rRNA indicate no closer relationship between Thermosphaera and Sulfophobococcus.

\section{ACKNOWLEDGEMENTS}

We are grateful to K. O. Stetter for critical discussions. We wish to thank M. Bock, P. Hummel and K. Eichinger for excellent technical assistance. This work was supported by grants of the Deutsche Forschungsgemeinschaft (Ste297/10) and the Fonds der Chemischen Industrie.

\section{REFERENCES}

1. Balch, W. E. \& Wolfe, R. S. (1976). New approach to the cultivation of methanogenic bacteria: 2-mercaptoethanesulfonic acid (HS-CoM)-dependent growth of Methanbacterium ruminantium in a pressurized atmosphere. Appl Environ Microbiol 32, 781-791.

2. Balch, W. E., Fox, G. E., Magrum, L. J., Woese, C. R. \& Wolfe, R. S. (1979). Methanogens: reevaluation of a unique biological group. Microbiol Rev 43, 260-296.

3. Barns, S. M., Fundyga, R. E., Jeffries, M. W. \& Pace, N. R. (1994). Remarkable archaeal diversity detected in a Yellowstone National Park hot spring environment. Proc Natl Acad Sci USA 91, 1609-1613.

4. Barns, S. M., Fundyga, R. E., Jeffries, M. W. \& Pace, N. R. (1994). Remarkable archaeal diversity detected in a Yellowstone National Park hot spring environment. Abstr 94th Gen Meet Am Soc Microbiol, abstract 253.

5. Blöchl, E., Burggraf, S., Fiala, G., Lauerer, G., Huber, G., Huber, R., Rachel, R., Segerer, A., Stetter, K. O. \& Völkl, P. (1995). Isolation, taxonomy and phylogeny of hyperthermophilic microorganisms. World J Microbiol Biotechnol 11, 1-8.

6. Blöchl E., Rachel, R., Burggraf, S., Hafenbradl, D., Jannasch, H. W. \& Stetter, K. O. (1997). Pyrolobus fumarii, gen. and sp. nov. represents a novel group of archaea, extending the upper temperature border of life to $113^{\circ} \mathrm{C}$. Extremophiles 1 , 14-21.

7. Brenner, D. J. (1973). Deoxyribonucleic acid reassociation in the taxonomy of enteric bacteria. Int J Syst Bacteriol 33, 298-307.

8. Brock, T. D., Brock, K. M., Belly, R. T. \& Weiss, R. L. (1972). Sulfolobus: a new genus of sulfur-oxidizing bacteria living at low pH and high temperature. Arch Mikrobiol 84, 54-68.

9. Bonch-Osmolovskaya, E. A., Slesarev, A. I., Miroshnichenko, M. L., Svetlichnaya, T. P. \& Alekseev, V. A. (1988). Characteristics of Desulfurococcus amylolyticus, a new extreme- thermophilic archaebacterium from hot volcanic vents of Kamchatka and Kunsashir. Microbiology (English translation of Mikrobiologiya) 57, 94-101.

10. Bonch-Osmolovskaya, E. A. \& Stetter, K. O. (1991). Interspecies hydrogen transfer in cocultures of thermophilic Archaea. Syst Appl Microbiol 14, 205-208.

11. Brosius, J., Palmer, J. L., Kennedy, J. P. \& Noller, H. F. (1978). Complete nucleotide sequence of a $16 \mathrm{~S}$ ribosomal RNA gene from Escherichia coli. Proc Natl Acad Sci USA 75, 4801-4805.

12. Burggraf, S., Huber, H. \& Stetter, K. O. (1997). Reclassification of the crenarchaeal orders and families in accordance with $16 \mathrm{~S}$ rRNA sequence data. Int J Syst Bacteriol 47, 657-660.

13. Burggraf, S., Jannasch, H. W., Nicolaus, B. \& Stetter, K. O. (1990). Archaeoglobus profundus sp. nov., represents a new species within the sulfate-reducing archaebacteria. Syst Appl Microbiol 13, 24-28.

14. De Rosa, M. \& Gambacorta, A. (1994). Archaeal lipids. In Chemical Methods in Prokaryotic Systematics, pp. 197-264. Edited by M. Goodfellow \& A. G. O’Donnell. Chichester: Wiley.

15. Fiala, G., Stetter, K. O., Jannasch, H. W., Langworthy, T. A. \& Madon, J. (1986). Staphylothermus marinus sp. nov. represents a novel genus of extremely thermophilic submarine heterotrophic archaebacteria growing up to $98^{\circ} \mathrm{C}$. Syst Appl Microbiol 8, 106-113.

16. Gillespie, S. \& Gillespie, D. (1971). Ribonucleic aciddeoxyribonucleic acid hybridization in aqueous solutions and in solutions containing formamide. Biochem $J \mathbf{1 2 5}$, $481-487$.

17. Gounot A. M. (1986). Psychrophilic and psychrotrophic microorganisms. Experientia 42, 1192-1197.

18. Herendeen, S. L., Van Bogelen, R. A. \& Neidhardt, F. C. (1979). Levels of major proteins of Escherichia coli during growth at different temperatures. J Bacteriol 139, 185-194.

19. Hoaki, T., Wirsen, C. O., Hanzawa, S., Maruyama, T. \& Jannasch, H. W. (1993). Amino acid requirements of two hyperthermophilic archaeal isolates from deep-sea vents, Desulfurococcus strain SY and Pyrococcus strain GB-D. Appl Environ Microbiol 59, 610-613.

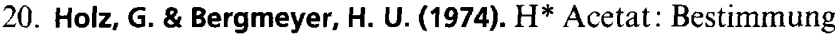
mit Acetat kinase und Hydroxylamin. In Methoden der Enzymatischen Analyse, pp. 1574-1578. Edited by H. U. Bergmeyer, Weinheim: Verlag Chemie.

21. Huber, R., Burggraf, S., Mayer, T., Barns, S. M., Roßnagel, P. \& Stetter, K. O. (1995). Isolation of a hyperthermophilic archaeum predicted by in situ RNA analysis. Nature 376, $57-58$.

22. Huber, R., Burggraf, S., Mayer, T., Barns, S. M., Roßnagel, P. \& Stetter, K. O. (1996). Isolation of hyperthermophilic archaea predicted by in situ $16 \mathrm{~S}$ rRNA analysis. Abstracts of the 11th Annual Meeting of VAAM. Abstract PB054, p. 84.

23. Huber, R., Kristjansson, J. K. \& Stetter, K. O. (1987). Pyrobaculum gen. nov., a new genus of neutrophilic, rod-shaped archaebacteria growing optimally at $100^{\circ} \mathrm{C}$. Arch Microbiol 149, 95-101.

24. Huber, R., Roßnagel, P., Woese, C. R., Rachel, R., Langworthy, T. A. \& Stetter, K. O. (1996). Formation of ammonium from nitrate during chemolithoautotrophic growth of the extremely thermophilic bacterium Ammonifex degensii gen. nov. sp. nov. Syst Appl Microbiol 19, 40-49. 
25. Huber, R., Stöhr, J., Hohenhaus, S., Rachel, R., Burggraf, S., Jannasch, H.W. \& Stetter, K. O. (1995). Thermococcus chitonophagus sp. nov., a novel, chitin-degrading, hyperthermophilic archaeum from a deep-sea hydrothermal vent environment. Arch Microbiol 164, 255-264.

26. Huber, R., Wilharm, T., Huber, D., Trincone, A., Burggraf, S., König, H., Rachel, R., Rockinger, I., Fricke, H. \& Stetter, K. O. (1992). Aquifex pyrophilus gen.nov. sp.nov., represents a novel group of marine hyperthermophilic hydrogen-oxidizing bacteria. Syst Appl Microbiol 15, 340-351.

27. Isaksen, M. F. \& Jørgensen, B. B. (1996). Adaptation of psychrophilic and psychrotrophic sulfate-reducing bacteria to permanently cold marine environments. Appl Environ Microbiol 62, 408-414.

28. Jander, G. \& Blasius, E. (1987). Einführung in das anorganischchemische Praktikum. Stuttgart: S. Hirzel Verlag.

29. Jannasch, H. W., Wirsen, C. O., Molyneaux, S. J. \& Langworthy, T. A. (1988). Extremely thermophilic fermentative archaebacteria of the genus Desulfurococcus from deepsea hydrothermal vents. Appl Environ Microbiol 54, 12031209.

30. Kane, M. D., Poulsen, L. K. \& Stahl, D. A. (1993). Monitoring the enrichment and isolationof sulfate-reducing bacteria by using oligonucleotide hybridization probes designed from environmentally derived $16 \mathrm{~S}$ rRNA sequences. Appl Environ Microbiol 59, 682--686.

31. Kelly, R. B., Cozzarelli, N. R., Deutscher, M. P., Lehman, J. R. \& Kornberg, A. (1970). Enzymatic synthesis of deoxyribonucleic acid. XXXII. Replication of duplex deoxyribonucleic acid by polymerase at a single strand break. $J$ Biol Chem 245, 39-45.

32. König, H. (1984). Isolation and characterization of Methanobacterium uliginosum sp. nov. from a marshy soil. Can $J$ Microbiol 30, 1477-1481.

33. Lauerer, G., Kristjansson, J. K., Langworthy, T. A., König, H. \& Stetter, K. O. (1986). Methanothermus sociabilis $\mathrm{sp.} \mathrm{nov.,} \mathrm{a}$ second species within the Methanothermaceae growing at $97^{\circ} \mathrm{C}$. Syst Appl Microbiol 8, 100-105.

34. Lowry, O. H., Rosebrough, N. J., Farr, A. L. \& Jandell, R. J. (1951). Protein measurement with the folin phenol reagent. $J$ Biol Chem 193, 265-275.

35. Marmur, J. \& Doty, P. (1961). Thermal renaturation of deoxyribonucleic acids. $J$ Mol Biol 3, 585-594.

36. Marmur, J. \& Doty, P. (1962). Determination of the base composition of deoxyribonucleic acid from its thermal denaturation temperature. $J$ Mol Biol 5, 109-118.

37. Meyer, S. A. \& Schleifer, K. H. (1978). Deoxyribonucleic acid reassociation in the classification of coagulase-positive staphylococci. Arch Microbiol 117, 183-188.

38. Miller, G. L. (1959). Use of dinitrosalicylic acid reagent for determination of reducing sugar. Anal Chem 31, 426-428.

39. Miroshnichenko, M. L., Bonch-Osmolovskaya, E. A., Neuner, A., Kostrikina, N. A., Chernych, N. A. \& Alekseev, V. A. (1989). Thermococcus stetteri sp. nov., a new extremely thermophilic marine sulfur-metabolizing archaebacterium. Syst Appl Microbiol 12, 257-262.

40. Mullis, K. B. \& Faloona, F. A. (1987). Specific synthesis of DNA in vitro via a polymerase-catalysed chain reaction. Methods Enzymol 155, 335-350.
41. Peters, J., Nitsch, M., Kühlmorgen, B. \& 10 other authors (1995). Tetrabrachion: A filamentous archaebacterial surface protein assembly of unusual structure and extreme stability. J Mol Biol 245, 385-401.

42. Peterson, G. L. (1979). Review of the folin phenol protein quantitation method of Lowry, Rosebrough, Farr, and Randall. Anal Biochem 100, 201-220.

43. Saiki, R. K., Gelfand, D. H., Stoffel, S., Scharf, S. J., Higuchi, R., Horn, G. T., Mullis, K. B. \& Erlich, H. A. (1988). Primerdirected enzymatic amplification of DNA with thermostable DNA polymerase. Science 239, 487-491.

44. Saiki, R. K., Scharf, S. J., Faloona, F., Mullis, K. B., Horn, G. T., Erlich, H. A. \& Arnheim, N. (1985). Enzymatic amplification of $\beta$-globin genomic sequences and restriction site analysis for diagnosis of sickle cell anemia. Science 230, 1350-1354.

45. Segerer, A. H., Trincone, A., Gahrtz, M. \& Stetter, K. 0. (1991). Stygiolobus azoricus gen. nov., sp. nov., represents a novel genus of anaerobic, extremely thermoacidophilic archaebacteria of the order Sulfolobales. Int J Syst Bacteriol 41, 495-501.

46. Stetter, K. O. (1992). Life at the upper temperature border. In Frontiers of Life, pp. 195-519. Edited by J. Tran Thanh Van, K. Tran Thanh Van, J. C. Mounolou, J. Schneider \& C. McKay. Gif-sur-Yvette: Editions Frontières.

47. Stetter, K. O. (1995). Microbial life in hyperthermal environments. ASM News 61, 285-290.

48. Stetter, K. O., Fiala, G., Huber, G., Huber, R. \& Segerer, A. (1990). Hyperthermophilic microorganisms. FEMS Microbiol Rev 75, 117-124.

49. Stetter, K. O., Segerer, A., Zillig, W., Huber, G., Fiala, G., Huber, R. \& König, H. (1986). Extremely thermophilic sulfurmetabolizing archaebacteria. Syst Appl Microbiol 7, 393397.

50. Trincone, A., Lanzotti, V., Nicolaus, B., Zillig, W., De Rosa, M. \& Gambacorta, A. (1989). Comparative lipid composition of aerobically and anaerobically grown Desulfurolobus ambivalens, an autotrophic thermophilic archaeon. J Gen Microbiol 135, 2751-2757.

51. VölkI, P., Huber, R., Drobner, E., Rachel, R., Burggraf, S., Trincone, A. \& Stetter, K. O. (1993). Pyrobaculum aerophilum sp. nov., a novel nitrate-reducing hyperthermophilic archaeum. Appl Environ Microbiol 59, 2918-2926.

52. Wheelis, M. L., Kandler, O. \& Woese, C. R. (1992). On the nature of global classification. Proc Natl Acad Sci USA 89, 2930-2934.

53. Wildhaber, I., Santarius, U. \& Baumeister, W. (1987). Threedimensional structure of the surface protein of Desulfurococcus mobilis. J Bacteriol 169, 5563-5568.

54. Woese, C. R., Kandler, O. \& Wheelis, M. L. (1990). Towards a natural system of organisms: proposal for the domains archaea, bacteria and eukarya. Proc Natl Acad Sci USA 87, 4576-4579.

55. Zillig, W., Stetter, K. O., Prangishvilli, D., Schäfer, W., Wunderl, S., Janekovic, D., Holz, I. \& Palm, P. (1982). Desulfurococcacae, the second family of the extremely thermophilic, anaerobic, sulfur-respiring Thermoproteales. Zentrabl Bakteriol Hyg Abt Orig C 3, 304-317.

56. Stetter, H. O. \& Gaag, G. (1983). Reduction of molecular sulphur by methanogenic bacteria. Nature 305, 309-311. 